096

Received: July 15, 2009

Accepted: November 15, 2009

\title{
FIBROLYTIC ENZYMES OF ANAEROBIC FUNGI ISOLATED FROM RUMINANT HERBIVORES
}

\author{
Natalija Atanasova-Pančevska, Džoko Kungulovski, Ivan Kungulovski \\ Microbiology Department, Institute of Biology, Faculty of Natural Sciences and Mathematics, \\ Gazi Baba bb, P.O. Box 162, 1000 Skopje, Republic of Macedonia \\ atanasovan@yahoo.com
}

\begin{abstract}
The cell wall of legume forages or grain feeds is principally cellulose, hemicellulose and lignin that are resistant to degradation. Although ruminants do not themselves secrete enzymes capable of digesting these substances, bacteria and fungi in the rumen produce enzymes capable of degrading cell wall substances. Anaerobic rumen fungi inhabit the rumen and actively degrade plant cell walls. They produce high levels of cellulases and hemicellulases; these enzymes are regulated by substrate (especially soluble sugars) available to the organisms. The aim of this paper was examination of presence of fibrolytic enzymes of anaerobic fungi isolated from ruminant herbivores. Ten anaerobic fungi isolated from ruminant herbivores were identified and analyzed. The capacity of hydrolysis of cellulases was monitored following the growth of Whatman $\mathrm{N}^{0} 1$, carboxymethyl cellulose (CMC) and Avicel. Their efficacies were defined by the presence of reducing sugars and production of gas. Enzyme activity was detected extracellularly in culture supernatants after vegetative growth. Based on overall results obtained, it could be concluded that all examined isolates gives glucose as a final product of fermentation of carbohydrates, followed with gas production in all the tested isolates. Also, the enzymes CM-cellulose, FP-ase and avicelase secreted from J3 released the largest quantity of reducing sugars and gas, compared to the other isolates.
\end{abstract}

Key words: fermentation; ruminants; anaerobic fungi; gas production; cellulases

\section{ФИБРОЛИТИЧКИ ЕНЗИМИ ОД АНАЕРОБНИ ГАБИ ИЗОЛИРАНИ ОД ТРЕВОПАСНИ ПРЕЖИВНИ ЖИВОТНИ}

\begin{abstract}
Клеточниот sид на легуминозните кабасти храни и житата главно е изграден од целулоза, хемицелулоза и лигнин, кои се отпорни на деградација. Иако преживарите не излачуваат ензими кои се во состојба да ги сварат овие супстанции, бактериите и габите во руменот произведуваат ензими кои се во состојба да го разложат клеточниот sид на овие супстанции. Анаеробните руминални габи го населуваат руменот и активно го разложуваат клеточниот sид на растенијата. Тие произведуваат големи количини целулази и хемицелулази; овие ензими се регулирани со супстрат достапен за организмите (особено растворливи шеќери). Целта на овој труд беше истражување на присуството на фибролитичките ензими на анаеробните габи изолирани од тревопасните преживни животни. Беа идентификувани и анализирани десет анаеробни габи изолирани од тревопасните преживни животни. Капацитетот на хидролизата на целулазита беше набљудуван следејќ го растежот по Ватман № 1, карбоксиметил целулоза (CMC) и авицел. Нивното дејство беше дефинирано преку присуството на редуцирани шеќери и производството на гас. Ензимската активност беше детектирана екстрацелуларно во културите на супернатантите по вегетативен пораст. Врз база на добиените резултати може да се заклучи дека сите испитани изолати даваат глукоза како краен продукт на ферментацијата на јаглехидратите, проследено со производство на гас кај сите тестирани изолати. Исто така, ензимите СМцелулоза, FР-аза и авицелаза излачени од J3 ослободуваат најголема количина редуцирани шеќери и гас споредено со другите изолати.
\end{abstract}

Клучни зборови: ферментација; преживари; анаеробни габи; производство на гас; целулаза 


\section{INTRODUCTION}

Anaerobic fungi are normal members of the rumen microflora (Mountfort, 1987) and are especially abundant in ruminants receiving highly fibrous diets (Bauchop, 1979). They have been isolated from many sites along the digestive tract of ruminants (Trinci et al., 1994) and from faeces (McGranaghan et al., 1999). Anaerobic fungi occur widely among many different species of herbivorous mammals, including ruminant and nonruminant animals.

As primary colonisers of freshly ingested forage, in concentration of $10^{3}-10^{5}$ zoospores $/ \mathrm{ml}$ (Kamra, 2005), these fungi (which produce some of the most powerful cellulases known to man) play an important role in the digestion, particularly when animals are fed on a fibrous low-quality diet (Trinci et al., 1994; Theodorou et al., 1995).

No information has been reported on the carbohydrate characteristics of the anaerobic fungi isolated from ruminant herbivores in Macedonia, since recently (Atanasova-Pančevska and Kungulovski, 2003/2004; Atanasova-Pancčevska and Kungulovski, 2008). In the present study, seven monocentric-type ruminal fungi and three polycentric-type ruminal fungi were isolated from ruminant herbivores. These isolates were characterized by their morphologies, gas production, and production of carbohydrate-degrading enzymes.

\section{MATERIALS AND METHODS}

\subsection{Isolates}

The anaerobic fungi used were isolate EZ2, isolated from faeces of Cervus dama (from the Skopje ZOO), isolates $\mathrm{J} 1, \mathrm{~J} 2$ and $\mathrm{J} 3$, from faeces of yak - Bos gruniens (from the Skopje ZOO), isolate L2, from faeces of Lama glama (from the Skopje ZOO), isolate Z2, from faeces of zebu Bos indicus (from the Skopje ZOO), isolate V4 isolated from faeces of vatus - Bos vatusi (from the Skopje ZOO), isolates SZ1 and SJ2, isolated from faeces of Capreolus capreolus (from the Skopje ZOO and from the Forest Reserve Jasen, Skopje), and isolate MR1, from the rumen content of Ovis musimon (from the Forest Reserve Jasen, Skopje). The cultures were maintained anaerobically at $39^{\circ} \mathrm{C}$, in serum bottles, containing M10 medium (Caldwell and Bryant, 1966), with CMC, and subcultured every three to four days.

\subsection{Culture purity}

Fungal isolates were routinely checked for purity by examination of wet mounts, Gram staining and transfer of isolates from liquid culture to agar plates containing medium with $0.2 \%$ cellobiose to check for bacterial colony formation.

\subsection{Morphological characteristics of anaerobic fungi}

The isolates were identified according to the colony morphology, the size of fungal rhizoids, and the appearance of zoospores, according to Ho and Barr, 1995.

\subsection{Production of cellulolytic enzymes}

Whatman $\mathrm{N}^{0} 1$, carboxymethyl cellulose (CMC) and Avicel were used as growth substrates for the production of cellulolytic enzymes. The inoculated serum bottles were incubated at $39^{\circ} \mathrm{C}$ for $12,24,36,48,60,72,84,96,108$ and 120 hours. Enzyme activities and the amount of gas produced were measured at the end of each incubation period. The utilization of the substrates was assayed at each time point using three biological replicates per fungal isolate. Five un-inoculated serum bottles were used as negative controls.

After incubation, the medium was centrifuged at $1500 \mathrm{~g}$ for 15 minutes, and the supernatant was tested for the presence of active enzymes.

With Whatman $\mathrm{N}^{\mathrm{o}} 1$ as the substrate, $1 \mathrm{ml}$ of supernatant was incubated with 1 strip of What$\operatorname{man} \mathrm{N}^{\circ} 1\left(6^{*} 1 \mathrm{~cm}=50 \mathrm{mg}\right)$ and $1 \mathrm{ml} 50 \mathrm{mM}$ citrate-phosphate buffer $(\mathrm{pH} 6.8)$ for 30 minutes at $30^{\circ} \mathrm{C}$. The reaction was terminated and reducing sugars were detected by the addition of $3 \mathrm{ml}$ of dinitrosalicylic acid reagent (DNS). The mixture was boiled for 15 minutes, and after cooling on ice, the A550 values were read with glucose as the standard.

With $\mathrm{CMC}$ as the substrate, $1 \mathrm{ml}$ of supernatant was incubated with $1 \mathrm{ml}$ of $1 \% \mathrm{CMC}$ and 1 $\mathrm{ml} 50 \mathrm{mM}$ citrate-phosphate buffer $(\mathrm{pH}$ 6.8) for 30 minutes at $30^{\circ} \mathrm{C}$. The reaction was terminated and reducing sugars were detected by the addition of 3 $\mathrm{ml}$ of dinitrosalicylic acid reagent (DNS). The mixture was boiled for 15 minutes, and after cooling on ice, the A550 values were read with glucose as the standard. 
With Avicel as the substrate, $1 \mathrm{ml}$ of supernatant was incubated with $1 \mathrm{ml}$ of $1 \%$ Avicel and 1 $\mathrm{ml} 50 \mathrm{mM}$ citrate-phosphate buffer ( $\mathrm{pH}$ 6.8) for 30 minutes at $30^{\circ} \mathrm{C}$. The reaction was terminated and reducing sugars were detected by the addition of 3 $\mathrm{ml}$ of dinitrosalicylic acid reagent (DNS). The mixture was boiled for $15 \mathrm{~min}$., and after cooling on ice, the A550 values were read with glucose as the standard.

\subsection{In vitro gas production}

The total gas production during fermentation was measured with a $25 \mathrm{ml}$ glass syringe connected to a needle, which pierced through the butyl stopper into the head-space of the flask.

\subsection{Statistical analysis}

Statistical analysis was performed by using Duncan's new multiple range test according to the general linear model procedures of SAS.

\section{RESULTS}

\subsection{Description of fungal isolates}

Anaerobic rumen fungi are an unusual group of organisms, from the Chytridiomycetes, family of Neocalimastigaceae (http://www.indexfungorum.org) (Nicholson et al., 2005). There are six genera: Neocallimastix, Piromyces, Orpinomyces, Anaeromyces, Caecomyces and Cyllamyces (Ozkose et al., 2001).

Table 2
Anaerobic fungi are found in the gastro-intestinal tract of all herbivorous mammals. Physiologically, rumen fungi are very interesting. They utilise a wide range of enzymes, among them powerful cellulases and xylanases that degrade cellulose and hemicellulose, respectively.

In this paper we examine the carbohydratedegradation and morphological characteristics of anaerobic fungi isolated from various ruminant herbivores (lama, zebu, yak, vatus, fellow deer, doe and mouflon) grown on Whatman $\mathrm{N}^{\mathrm{o}} 1$, carboxymethyl cellulose and Avicel. Ten isolates were cultured and described (Table 1). Seven isolates were monocentric, and three were polycentric (Table 2). Some of their growth patterns are illustrated in Figures 1 to 4.

Table 1

Overview of studied isolates of anaerobic rumen fungi

\begin{tabular}{lccr}
\hline \hline Animal & Origin & Source & Isolate \\
\hline Lama (Lama glama) & ZOO Skopje & Faeces & L2 \\
Zebu (Bos indicus) & ZOO Skopje & Faeces & Z2 \\
Yak (Bos gruniens) & ZOO Skopje & Faeces & J1, J2, J3 \\
Vatus (Bos vatusi) & ZOO Skopje & Faeces & V4 \\
Fellow deer (Cervus dama) & ZOO Skopje & Faeces & EZ2 \\
Doe (Capreolus capreolus) & ZOO Skopje & Faeces & SZ1 \\
Doe (Capreolus capreolus) & FR Jasen & Faeces & SJ2 \\
Mouflon (Ovis musimon) & FR Jasen & Rumen & MR1 \\
& & content & \\
\hline \hline
\end{tabular}

List of identified isolates of anaerobic rumen fungi

\begin{tabular}{|c|c|c|c|c|c|c|c|c|c|c|}
\hline Isolate & MR1 & $\mathrm{Z2}$ & $\mathrm{J} 3$ & EZ2 & SZ1 & $\mathrm{J} 1$ & $\mathrm{SJ} 2$ & $\mathrm{~J} 2$ & L2 & V4 \\
\hline Source & $\begin{array}{l}\text { rumen } \\
\text { content }\end{array}$ & faeces & faeces & faeces & faeces & faeces & faeces & faeces & faeces & faeces \\
\hline Origin & FR Jasen & $\mathrm{ZOO}$ & $\mathrm{ZOO}$ & $\mathrm{ZOO}$ & $\mathrm{ZOO}$ & $\mathrm{ZOO}$ & FR Jasen & $\mathrm{ZOO}$ & $\mathrm{ZOO}$ & $\mathrm{ZOO}$ \\
\hline Diameter of sporangium $(\mu \mathrm{m})$ & 42 & 83.61 & 59 & 157.14 & $31 * 115$ & $29.3 * 83.4$ & 171 & $28 * 106$ & no data & no data \\
\hline Diameter of zoospore $(\mu \mathrm{m})$ & $7-15$ & $7-22$ & $5-18$ & $10-25$ & $3.1-8$ & $2-12.3$ & $5.5-7$ & $7-8.5$ & no data & no data \\
\hline Number of flagella & $7-30$ & $7-30$ & $7-30$ & $10-30$ & 1 & 1 & 1 & 1 & no data & no data \\
\hline Genus & $\begin{array}{c}\text { Neocalli- } \\
\text { mastix }\end{array}$ & $\begin{array}{l}\text { Neocalli } \\
\text {-mastix }\end{array}$ & $\begin{array}{l}\text { Neocalli- } \\
\text { mastix }\end{array}$ & $\begin{array}{c}\text { Neocalli- } \\
\text { mastix }\end{array}$ & Piromyces & Piromyces & Piromyces & $\begin{array}{c}\text { Anaero- } \\
\text { myces }\end{array}$ & $\begin{array}{c}\text { Anaero- } \\
\text { myces }\end{array}$ & $\begin{array}{l}\text { Poly- } \\
\text { centric }\end{array}$ \\
\hline Species & frontalis & frontalis & frontalis & frontalis & mae & mae & minutus & elegans & sp. & / \\
\hline
\end{tabular}




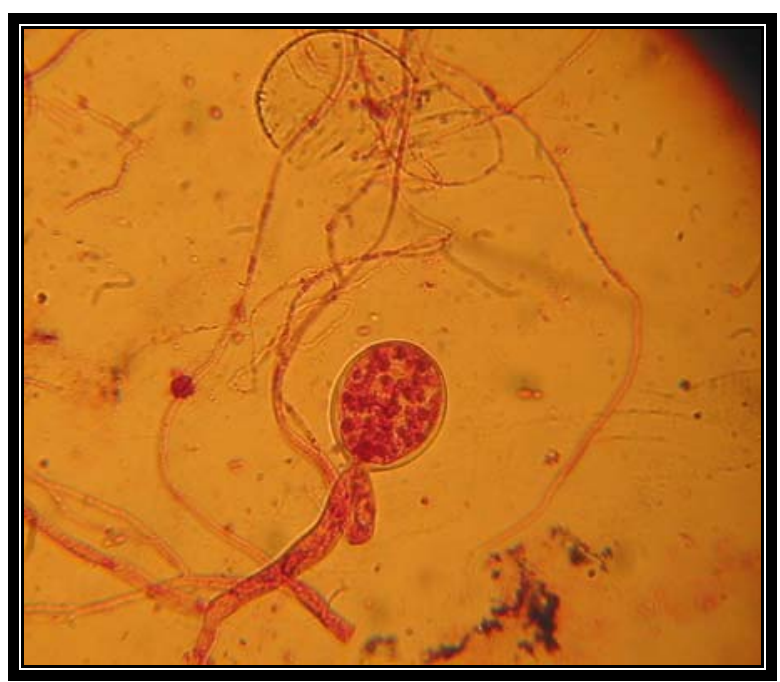

Figure 1. Isolate MR1 - Neocallimastix frontalis, sporangium with long sporangiophore, with spores (magnification $400 \times$ )

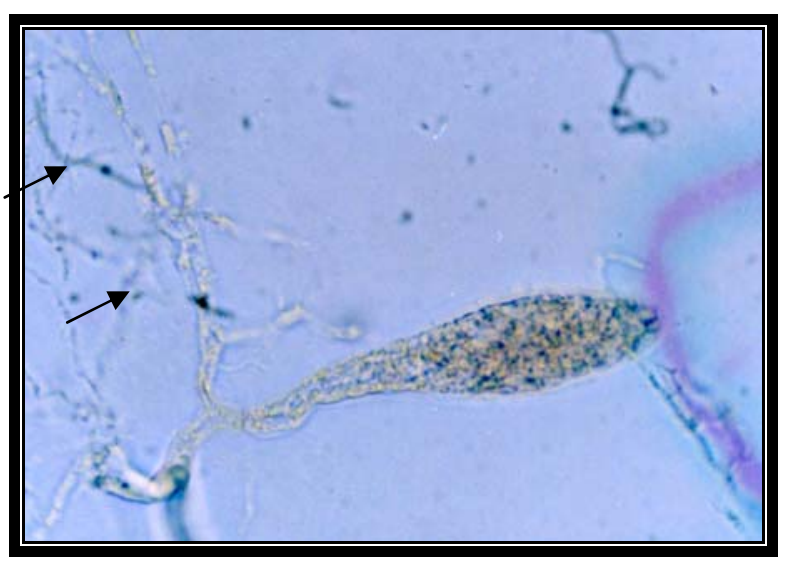

Figure 2. Isolate J2 - Anaeromyces elegans, polycentric isolate. Magnification $450 \times$. Arrows-constricted hiphas

\subsection{Enzyme activity}

We examined the capacity of hydrolysis of cellulases from isolated anaerobic fungi. The growth pattern of isolated anaerobic fungi on various growth substrates is shown on Table 3 . Their efficacies were defined by the presence of reducing sugars and production of gas. The results are shown in Figure 5. Anaerobic fungi metabolize carbohydrates via mixed acid-type fermentation.

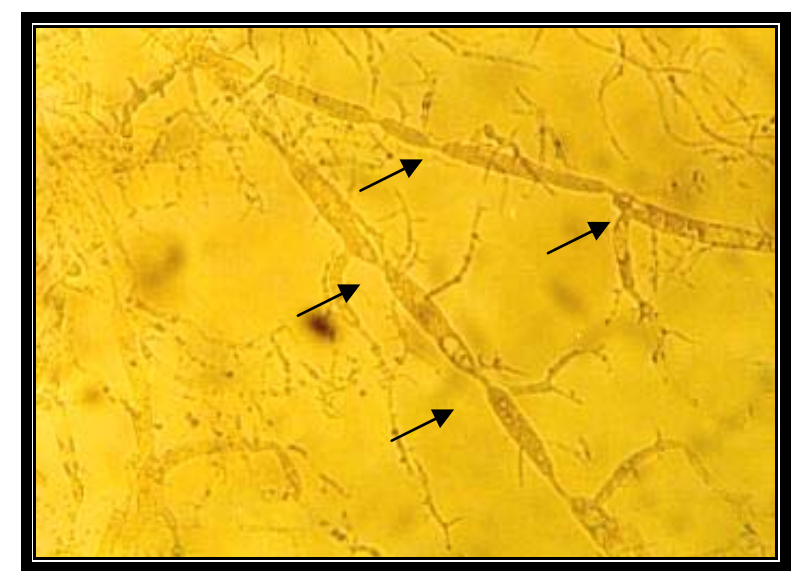

Figure 3. Isolate L2 - Anaeromyces spp., polycentric isolate. Magnification $400 \times$. Arrows- constricted hiphas

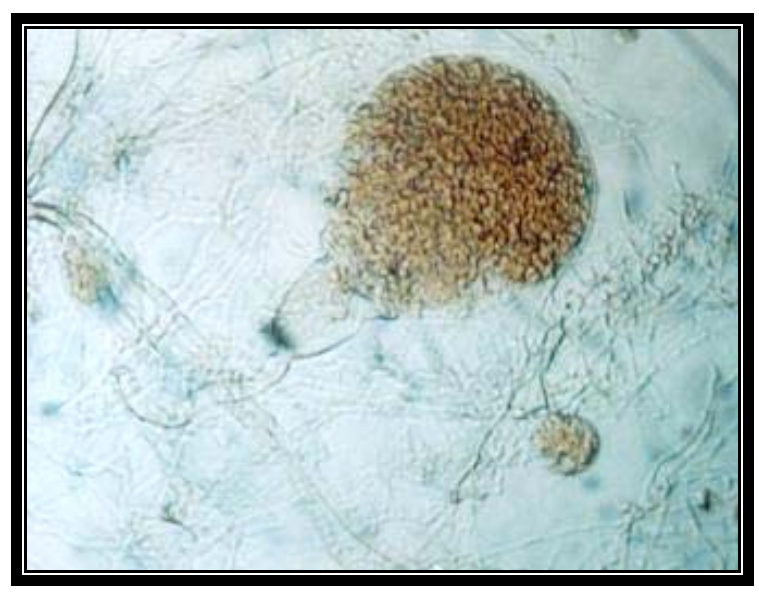

Figure 4. Isolate Z2 - Neocallimastix frontalis, egzogenous sporangium with short, egg-like sporangiophore, full with spores (magnification $900 \times$ )

The isolates were initially isolated on medium M10 with glucose as a sole carbohydrate source, and then were grown on Whatman $\mathrm{N}^{\circ} 1$, carboxymethyl cellulose (CMC) and Avicel, as a growth substrate. All isolates produced an array of enzymes that allowed them to hydrolyze plant cell walls. The enzymatic activity paralleled the growth of the isolate, as it has been the case with other ruminal fungi (Mountfort and Asher, 1985; Lowe, Theodorou and Trinci, 1987).

Table 3

\section{Growth pattern of isolated anaerobic fungi on various growth substrates}

\begin{tabular}{|c|c|c|c|c|c|c|c|c|c|c|}
\hline \multirow{2}{*}{$\begin{array}{l}\text { Isolated anaerobic } \\
\text { fungi }\end{array}$} & \multicolumn{4}{|c|}{ Neocallimastix frontalis } & \multicolumn{2}{|c|}{ Piromyces mae } & \multirow{2}{*}{$\begin{array}{l}\text { Piromyces } \\
\text { minutus } \\
\text { SJ2 }\end{array}$} & \multirow{2}{*}{$\begin{array}{c}\text { Anaeromyces } \\
\text { elegans } \\
\text { J2 }\end{array}$} & \multirow{2}{*}{$\begin{array}{c}\text { Anaeromyces } \\
\text { spp. } \\
\text { L2 }\end{array}$} & \multirow{2}{*}{$\begin{array}{c}\text { Polycentric } \\
\text { species } \\
\text { V4 }\end{array}$} \\
\hline & MR1 & $\mathrm{Z} 2$ & $\mathrm{~J} 3$ & EZ2 & SZ1 & $\mathrm{J} 1$ & & & & \\
\hline \multicolumn{11}{|l|}{ Growth substrate } \\
\hline Whatman $\mathrm{N}^{\mathrm{o}} 1$ & + & + & + & + & + & + & + & - & - & - \\
\hline CMC & + & + & + & + & + & + & + & - & - & + \\
\hline Avicel & - & + & + & - & + & - & - & - & - & - \\
\hline
\end{tabular}




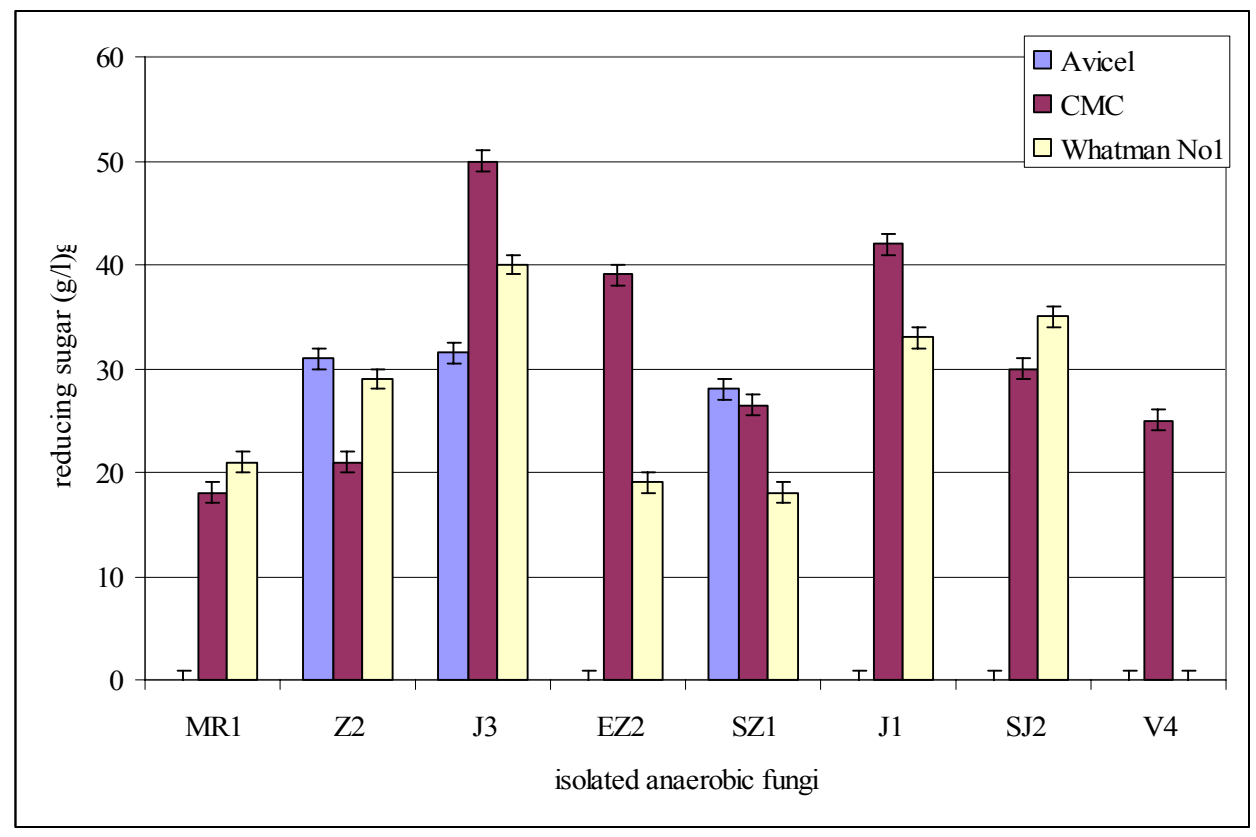

Figure 5. Concentration of reducing sugars present in supernatants of eight ruminal fungal isolates actively growing on Avicel, CMC and Whatman $\mathrm{N}^{\circ} 1$.

\subsection{In vitro gas production}

Gas production was measured during fermentation of Whatman $\mathrm{N}^{0} 1$, carboxymethyl cellulose (CMC) and Avicel. The amount of gas produced was determined after $12,24,36,48,60,72$,
84, 96, 108 and 120 hours. The results are shown in Figures 6, 7, 8 and 9. The increase in the production of total gas for all strains was accompanied by an increase of glucose in the culture medium, suggesting that glucose had a regulatory role.

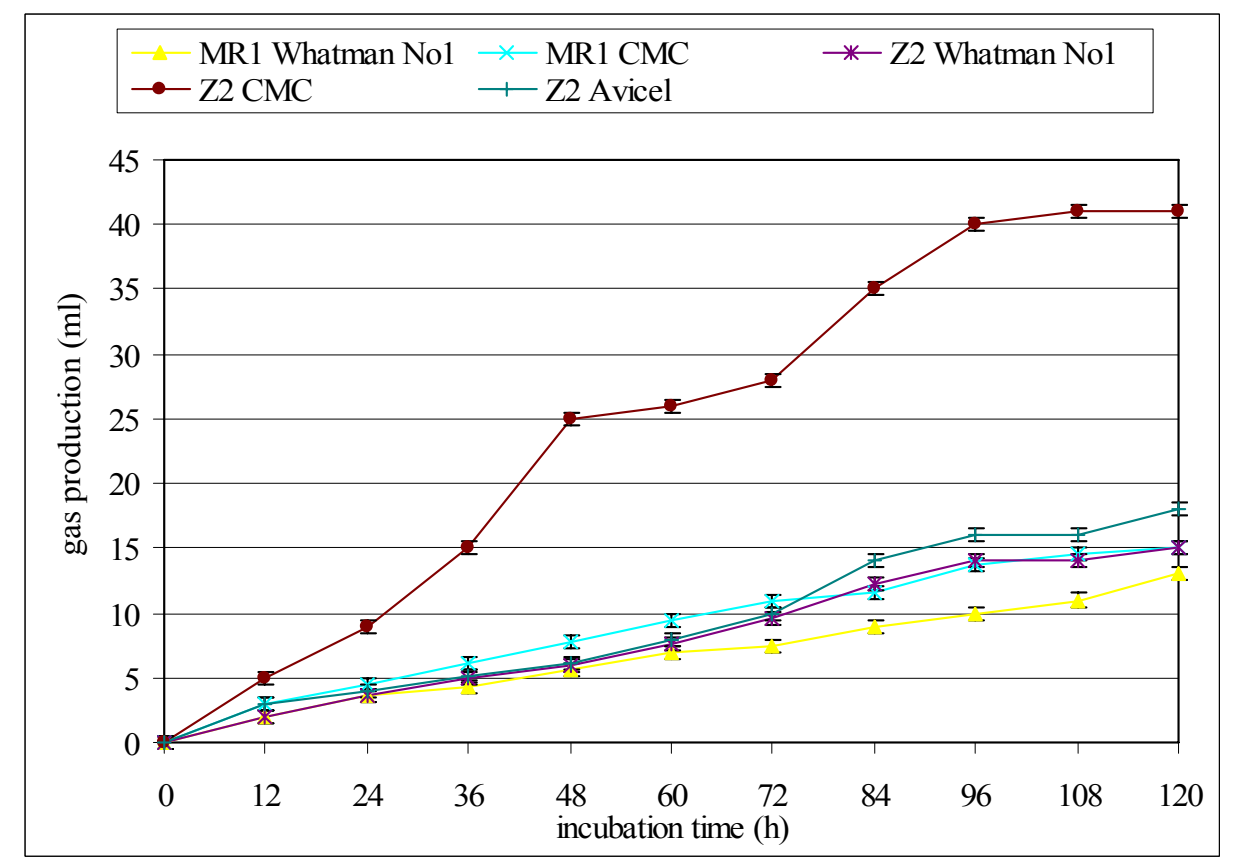

Figure 6. Gas production when strains MR1 and Z2 were incubated on M10 with different carbohydrates as an energy source (mean with SE, $n=3$ ). 


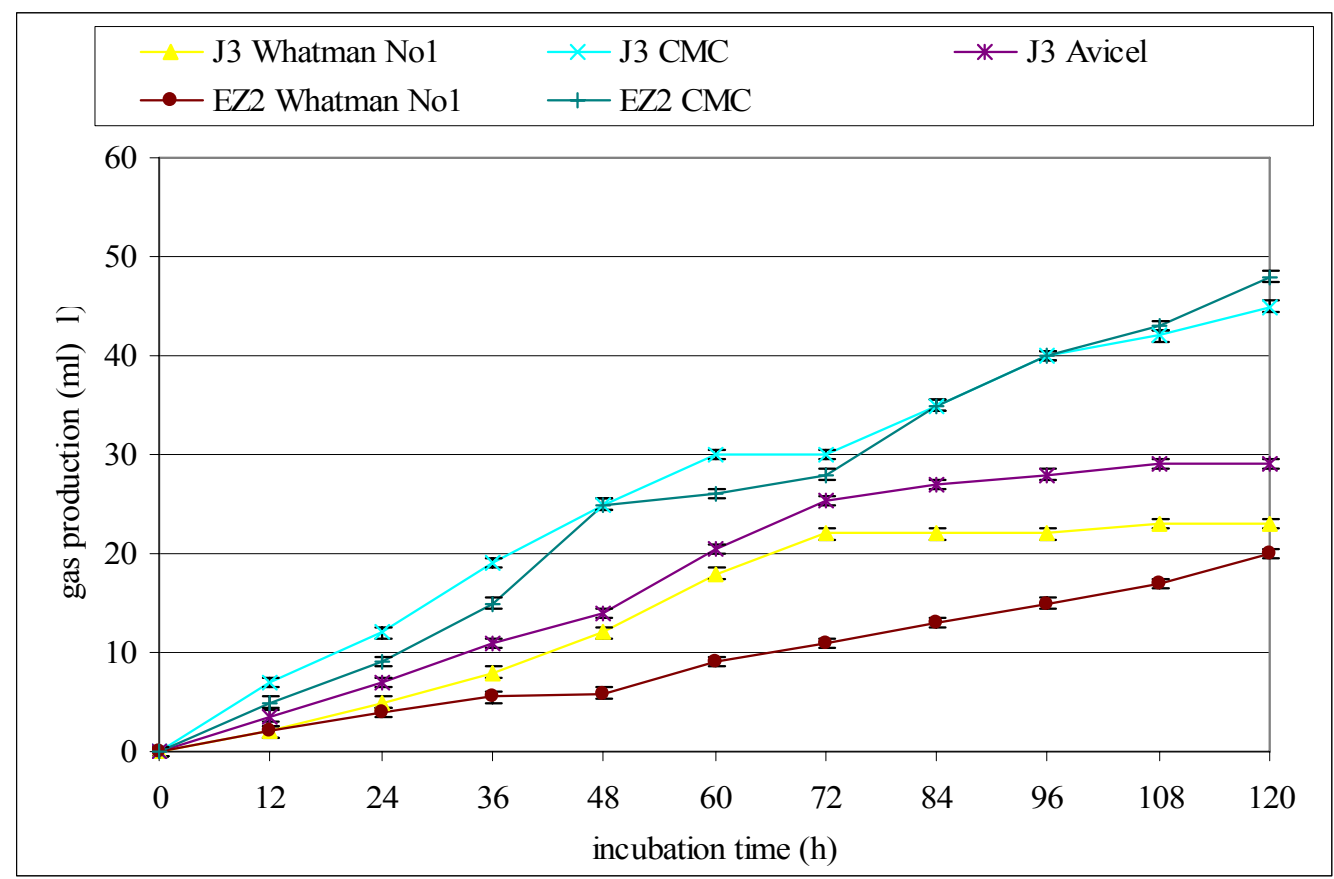

Figure 7. Gas production when strains $\mathrm{J} 3$ and EZ2 were incubated on M10 with different carbohydrates as an energy source (mean with $\mathrm{SE}, n=3$ ).

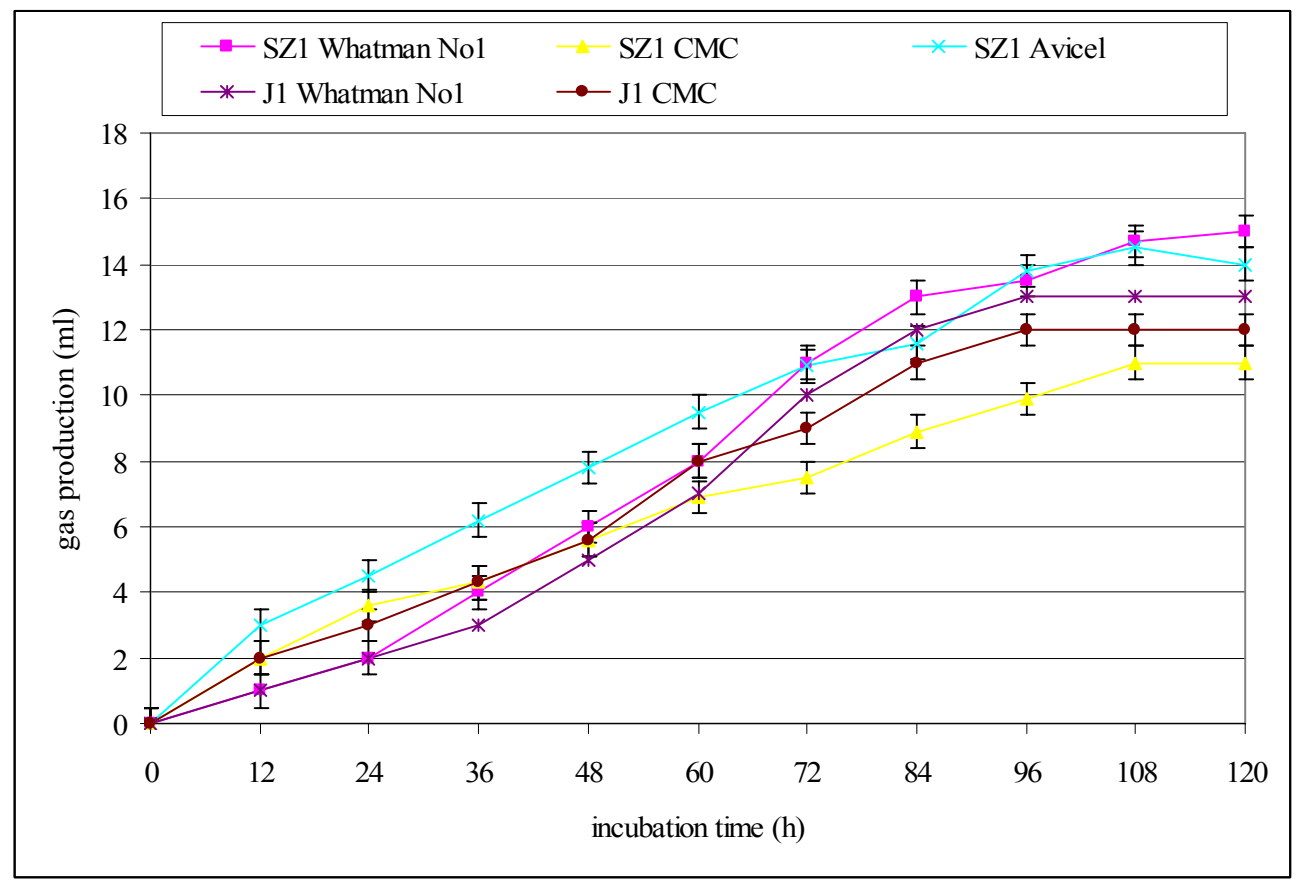

Figure 8. Gas production when strains J1 and SZ1 were incubated on M10 with different carbohydrates as an energy source (mean with $\mathrm{SE}, n=3$ ). 


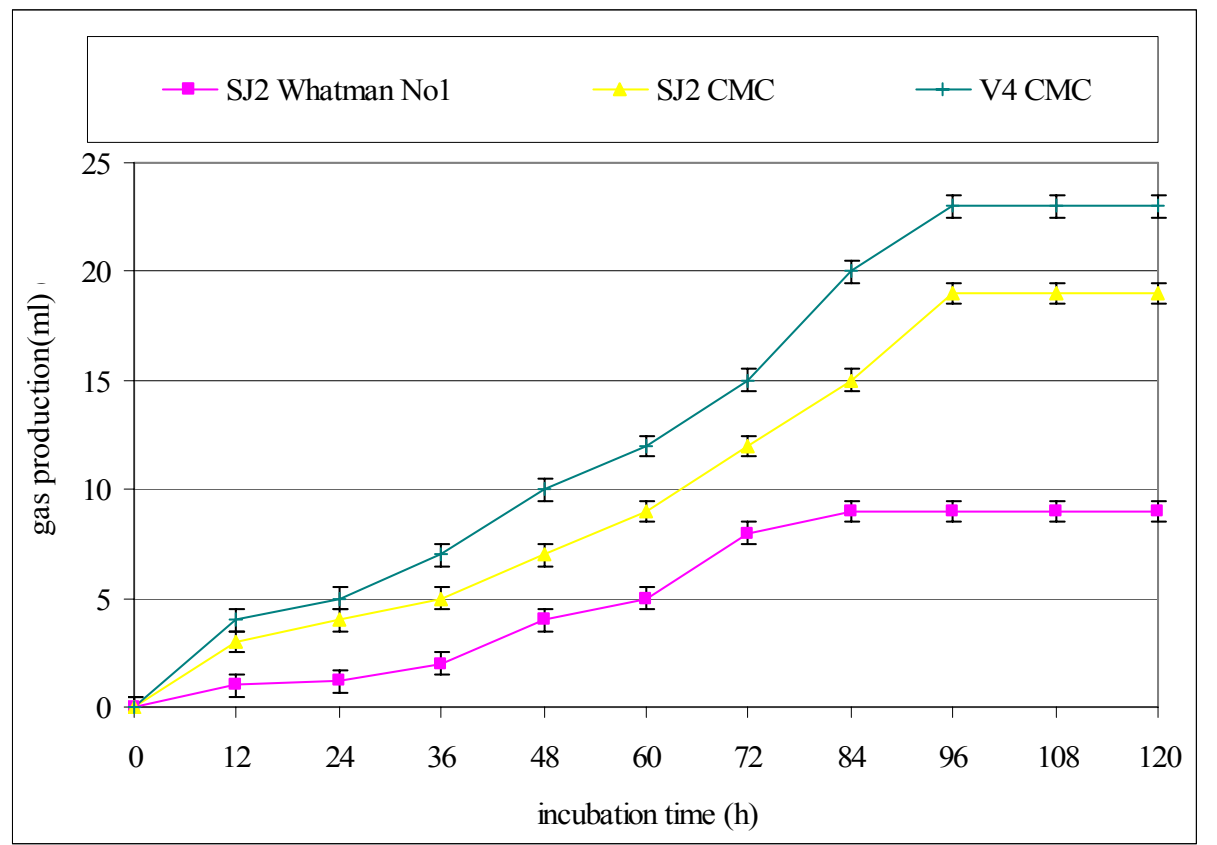

Figure 9. Gas production when strains SJ2, J2, L2 and V4 were incubated on M10 with different carbohydrates as an energy source (mean with $\mathrm{SE}, n=3$ )

\section{DISCUSSION}

\subsection{Description of fungal isolates}

The fungal isolates were classified according to the colonial morphology, the size of the fungal rhizoid, and the appearance of the zoospores. The isolates reported in this study were representatives of three genera of fungi, and one isolate unclassified, found in ruminants.

All ten isolates were identified according to the colony morphology, the size of fungal rhizoids, and the appearance of zoospores (Table 2), according to Ho and Barr, 1995. Seven of them (isolate MR1, Z2, J3, EZ2, SZ1, J1 and SJ2) have monocentric growth patterns, with new colonies developing from zoospores. They were obtained from faeces; only isolate MR1 (Figure 1) was from the rumen content. Two monocentric isolates (MR1 and SJ2) were from animals kept in Forest Reserve Jasen - Skopje, and other five were from animals from Skopje ZOO.

The other three isolates (L2, J2 and V4) showed growth characteristics similar to those of the polycentric fungi. All three isolates were from animals from Skopje ZOO. Isolate J2, according to morphological characteristics, was identified as Anaeromyces elegans; isolate L2 was identified as genus Anaeromyces, while isolate V4 was not identified to the genus level; we only know that it showed polycentric characteristics.

The taxonomy of anaerobic ruminal fungi relies on zoospore ultra structure; therefore, the true taxonomic status of the isolates studied, clearly remains to be determined.

\subsection{Enzyme activity}

One of the main tasks in our laboratory is focussed on plant cell wall-degrading enzymes of anaerobic fungi that are particularly active against the more recalcitrant plant structural polysaccharides. These organisms produce cellulases and hemicellulases that associate into large molecular weight multienzyme complexes, called cellulosomes, and bind tightly to cellulose.

In this paper we study the capacity of hydrolysis of cellulases from the selected isolates of anaerobic fungi. The capacity was defined by the presence of reducing sugars and production of gas. Enzyme activity was detected extracellularly in culture supernatants, through reducing sugars, after vegetative growth. Experiments for degradation were carried with $\mathrm{CMC}$, Whatman $\mathrm{N}^{\mathrm{O}} 1$ and Avicel, as a source of cellulose, after $36 \mathrm{~h}$ incubation.

Our isolates, tested in this study released cellulolytic enzymes mainly into the culture fluid, which efficiently degrades highly ordered crystal- 
line cellulose, like other examined anaerobic fungi (Li et al., 1992; Mountfort and Asher, 1988, Wood et al., 1988; Wood et al., 1986). When cultures of anaerobic fungi were grown on CMC, Avicel and Whatman $\mathrm{N}^{\circ} 1$, maximal activities obtained corresponded to maximal growth. This is also observed in the paper of Mountfort and Asher (1988), with Neocallimastix frontalis as test culture.

The failure of isolate $\mathrm{J} 2$ and $\mathrm{L} 2$ to degrade CMC (Table 3) used in our study was enigmatic, since these anaerobic fungi grow previously on medium M10 with CMC. It is possible that these isolates produce an intracellular cellulase activity which is not examined in this study.

Reducing sugars in culture supernatant began to accumulate during growth on $\mathrm{CMC}$, Whatman $\mathrm{N}^{\mathrm{o}} 1$ and Avicel ca. $36 \mathrm{~h}$ after inoculation, similar to Lowe et al. (1987). By the end of $36 \mathrm{~h}$, maximum reducing sugar concentrations were maximum at isolate $\mathrm{J} 3$ on CMC $(50 \mathrm{~g} / \mathrm{l})$ following isolates J1, EZ2 and SJ2 (Figure 5). Reducing sugars were also detected during fermentations of Avicel and Whatman $\mathrm{N}^{\mathrm{o}} 1$, with maximum concentration at isolate J3. Similar results have been reported for $N$. frontalis growing on the filter paper (Mountfort and Asher,. 1985; Pearce and Bauchop, 1985), although unlike results in the present study, reducing sugars were not detected during growth on Avicel (Pearce and Bauchop, 1985).

From Figure 5 it is clear that isolate $\mathrm{J} 3$ is the most active isolate from all tested anaerobic fungi. The enzymes CM-cellulose, FP-ase and avicelase secreted from $\mathrm{J} 3$ released the largest quantity of reducing sugars, compared to the other isolates.

\subsection{In vitro gas production}

During the last 3 decades, measurement of in vitro microbial gas production (MGP) has received great impetus and become increasingly popular for determining the rate of fermentation (Menke et al., 1979; Theodorou et al., 1994; Davies et al., 2000).

The syringe system is used widely to record the gas values at different times of incubation (Duan et al., 2006).

This method for measuring gas production as an index of activity in vitro was first described by Menke et al. (Menke et al., 1979).

As we expected, gas production increased simultaneously with the enzyme production in all the tested isolates (Figures 6 to 9). Monocentric isolates $\mathrm{J} 3, \mathrm{Z} 2$ and EZ2 produced a maximum of 45, 42 and $48 \mathrm{ml}$ gas, respectively, when incubated on M10 with CMC as the sole energy source, and 29 and $18 \mathrm{ml}$ gas, J3 and Z2 respectively (EZ2 didn't use Avicel - Table 3), when were incubated on M10 with Avicel as the sole energy source.

\section{CONCLUSION}

Anaerobic fungi colonize ingested the plant material in the rumen (Orpin, 1977) and hydrolyse the plant cell wall polymers by producing a range of highly active polysacharidases (Xue et al., 1992; Wood et al., 1994). Anaerobic fungi convert insoluble cellulose mainly to glucose (Pearce and Bauchop, 1985).

Based on the overall results obtained, it could be concluded that all the examined isolates give glucose as a final product of fermentation of carbohydrates, followed with gas production in all the tested isolates. Also, the enzymes CM-cellulose, FP-ase and avicelase secreted from $\mathrm{J} 3$ released the largest quantity of reducing sugars, compared to the other isolates.

As a conclusion, based on all of these observations, anaerobic fungi, isolated from ruminant herbivores have highly active fibrolytic enzymes and these enzymes are attractive for scientific research.

Acknowledgements. This work was supported by the Ministry of Education and Science of Republic of Macedonia.

\section{REFERENCES}

[1] Atanasova-Pančevska, N., Kungulovski, Dž. (2002/2003): Fermentation activities of some isolates of anaerobic fungi from Macedonia. God. zb. Biol., Skopje, 55/56, $21-$ 27.

[2] Atanasova-Pančevska, N., Kungulovski, Dž. (2008): Comparison of morphological and enzyme characteristics of anaerobic fungi isolated from Cervus dama. Cent. Eur. J. Biol., 3 (1), 69-74.

[3] Caldwell, D. R., Bryant, M. P. (1966): Medium without rumen fluid for nonselective enumeration and isolation of rumen bacteria. Appl. Microbiol. 14, 794.

[4] Chen, H., Li, X. L., Ljungdahl, L. G. (1995): Biomass degrading enzymes from anaerobic rumen fungi. SAAS Bull. Biochem. Biotechnol. 8, 1-6.

[5] Davies, Z. S., Mason, D., Brooks, A. E., Griffith, G. W., Merry, R. J., Theodorou, M. K. (2000): An automated system for measuring gas production from forages inocu- 
lated with rumen fluid and its use in determining the effect of enzymes on grass silage. Anim. Feed Sci. Technol. $83,205-221$.

[6] Duan, Z. Y., W. J. Yan, Y. M. Wu, J. A. Ye, J. X. Liu. (2006): Comparison of gas test system based on the syringe with the reading pressure technique. Journal of Animal and Feed Sciences. 15, 121-129.

[7] Ho, W. Y., Barr, D. J. S. (1995): Classification of anaerobic gut fungi from herbivores with emphasis on rumen fungi from Malaysia. Mycologia. 87, 655-677.

[8] Kamra, D. N. (2005): Rumen microbial ecosystem. Current Science, 89, 124-135.

[9] Lowe, S. E., Theodorou, M. K., Trinci, A. P. J. (1987): Cellulases and xylanases of an anaerobic rumen fungus grown on wheat straw, wheat straw holocellulose, cellulose, and xylan, Appl. Environ. Microbiol. 53, 12161223 .

[10] McGranaghan, P., Davies, J. C., Grifith, G. W., Davies, D. R., Theodorou, M. K. (1999): The survival of anaerobic fungi in cattle faeces. FEMS Microbiology Ecology. 29, 293-300.

[11] Menke, K., Raab, L., Salewski, A., Steingass, H., Fritz, D., Schneider, W. (1979): The estimation of digestibility and metabolizable energy content of ruminant feeding stuffs from the gas production when they are incubated with rumen liquor in vitro. J. Agric. Sci. 93, 217-222.

[12] Mountfort, D. O., Asher, R. A. (1985): Production and regulation of cellulase by two strains of the rumen anaerobic fungus Neocallimastux frontalis. Appl. Environ. Microbiol. 49, 1314-1322.

[13] Nicholson, M. J., Theodorou, M. K., Brookman, J. L. (2005): Molecular analysis of the anaerobic rumen fungus Orpinomyces - insights into an AT-rich genome. Microbiology. 151, 121-133.

[14] Orpin, C. G. (1977): Invasion of plant tissues in the rumen by the flagellate Neocallimastix frontalis. J. Gen. Microbial. 98, 423-430.

[15] Ozkose, E., Thomas, B. J., Davies, D. R., Griffith, G. W., Theodorou, M. K. (2001): Cyllamyces aberensis gen. nov. sp. nov., a new anaerobic gut fungus with branched sporangiophores isolated from cattle. Can. J. Bot. 79, 666-673.

[16] Pearce, P. D., Bauchop, T. (1985): Glycosidases of the rumen anaerobic fungus Neocallimastix frontalis grown on cellulosic substrates. Appl. Environ. Microbiol. 49, $1265-1269$.

[17] SAS Institute (1996): User's guide: statistics, version 6 editions. SAS Institute, Inc., Cary, N.C.

[18] Steel, R. G. D., Torrie, J. H. (1980): Principles and procedures of statistics a biometrical approach. McGrawHill International Book Company, New York.

[19] Theodorou, M. K., Williams, B. A., Dhanoa, M. S., McAllan, A. B., France, J. (1994): A simple gas production method using a pressure transducer to determine the fermentation kinetics of ruminant feeds. Anim. Feed. Sci. Technol. 48, 185-197.

[20] Theodorou, M. K., Davies, D. R., Orpin, C. G. (1995): Nutrition and survival of anaerobic fungi. In: Anaerobic Fungi: Biology, Ecology and Function (Mountfort, D.O. and Orpin, C.G., Eds.), 107-128, Marcel Dekker, New York, USA.

[21] Trinci, A. P. J., Davies, D. R., Gull, K., Lawrence, M. I., Nielsen, B. B., Rickers, A., Theodorou, M. K. (1994): Anaerobic fungi in herbivorous animals. Mycol. Res. 98, 129-152.

[22] Wood, T. M., Wilson, C. A., McCrea, S. I., Joblin, K. N. (1986): A highly active extracellular cellulase from the anaerobic rumen fungus Neocallimastix frontalis. FEMS Microbiol. Lett. 43, 37-40.

[23] Wood, T. M., McCrea, S. I., Wilson, C. A., Bhat, Gow, L. A. (1988): Aerobic and anaerobic fungal cellulases with special reference to their mode of attack on crystalline cellulose, p. 31-52. In J. P. Aubert, P. Beguin, and J. Millet (ed.), Biochemistry and genetics of cellulose degradation. Academic Press, Inc., New York.

[24] Wood, T. M., Wilson, C. A., McCrae, S. I. (1994): Synergism between components of the cellulase system of the anaerobic rumen fungus Neocallimastir frontalis and those of the aerobic fungi Penicillim pinophilum and Trichoderma koningii in degrading crystalline cellulose. Appl. Microbial. Biotechnol. 41, 257-261.

[25] Xue, G-P., Orpin, C. G., Gobius, K. S., Aylward, J. H., Simson, G. D. (1992): Cloning and expression of multiple cellulase cDNAs from the anaerobic rumen fungus Neocallimastix patriciarum in Escherichia coli. J. Gen. Microbial. 138, 1413-1420. 